Valóságos könyvtár - könyvtári valóság. Könyvtár- és információtudományi tanulmányok 2016. Szerk. Kiszl Péter, Boda Gáborné Köntös Nelli.

Budapest, ELTE BTK Könyvtár- és Információtudományi Intézet. 2017. 177-185.

\title{
ÚJ EREDMÉNYEK A 2010-ES ÉVEK KÖNYVTÁR- ÉS INFORMÁCIÓTUDOMÁNYÁBAN
}

\author{
SEBESTYÉN GYÖRGY \\ ELTE BTK KITI, professor emeritus
}

\begin{abstract}
ABSZTRAKT
A tanulmány az ELTE BTK Könyvtár- és Információtudományi Intézetében jelenleg folyó kutatásokba enged betekintést, különös tekintettel az e-könyvészetre, az elektronikus könyv problémakörére és a kulturális örökség hálózati reprezentálására, a közösségi média nyújtotta lehetőségekre és kihívásokra.
\end{abstract}

Bevezetés

A magyar könyvtáros szakma a 21. század első éveiben kidolgozott stratégiájának alaptétele: „az információs társadalom, a tudás alapú társadalom alapintézménye az információt gyưjtő, feltáró és szolgáltató intézmény: a könyvtár.”" Amennyiben a tudásalapú társadalom egyre gyorsabban és egyre dinamikusabban fejlődik, akkor ezzel az ütemmel az alapintézményének is lépést kell tartania.

A hazai és nemzetközi könyvtárügy különböző trendjeinek alapvető, közös vonása a felgyorsult fejlődésre való reagálás, a szüntelenül bekövetkező változások integrálása. Mindez új paradigmák sorozatos megjelenését és a meglévő kontextusok lényegi módosulását eredményezi, amely gazdagítja és bővíti az interdiszciplinaritást. A technológiai, gazdasági és társadalmi fejlődés minden egyes szakmában nélkülözhetetlenné teszi az egész életen át tartó tanulást és a tudatos karrierépítést. Különösen igaz mindez az informatikus könyvtáros hivatásban, amelyből következően a könyvtárosi pályaképet mindenkor a változásokhoz kell adaptálni és markánsan újra kell definiálni, vagy legalábbis módosítani.

A felsorolt faktorok soha nem tapasztalt mértékben kovácsolják egybe az egyetemeken folyó munka oktatási és kutatási vetületét. A jelenleg a felsőoktatásban tanuló szakembereknek, szakemberjelölteknek világosan kell látniuk: nem minden ma megtanulandó ismeret fogja egy életen keresztül szolgálni őket, még akkor sem, ha ezek birtoklása a közeljövőben kiemelt fontossággal bír. Képessé kell válnunk arra, hogy az egyre gyorsuló fejlődéshez folyamatosan tudjunk alkalmazkodni és pragmatikus módon elkerüljük a változások által generált illúziók csapdáit.

Hazánkban folyamatosan erősödik a tudásalapú társadalom, amelynek alapintézménye - mint korábban idéztük - a könyvtár. Az ELTE BTK Könyvtár- és Információtudományi Intézete mintegy zászlóshajója az informatikus könyvtáros képzésnek. Az Intézet a gyorsuló fejlődés közepette nemcsak az egyetemi oktató- és kutatómunka szigorú, nemzetközi normák szerinti folytatásával, de a kulturális és tudományos örökség gondozásával is foglalkozik. 


\section{SEBESTYÉN GYÖRGY}

A fenti helyzetet igen találóan fogalmazta meg Kisæl Péter (az ELTE Könyvtár- és Információtudományi Intézetének igazgatója, az ELTE BTK Irodalomtudományi Doktori Iskola Könyvtártudomány Doktori Programjának vezetője, a Könyvtár- és Információtudományi Képzések Kollégiumának elnöke), aki az Intézet kutatási és tudományos potenciáljáról a következőket írja: „A könyvtár- és információtudomány fókuszában a társadalom és az archiválható formába önthető információ közötti kapcsolat biztosítása, elemzése, a hozzáférés optimalizálása áll. Interdiszciplináris tudományterületünkön jelentős súlyponteltolódásokkal járt az információ rögzítésének és továbbításának megváltozása, a digitalizálás előtérbe kerülése, a hálózati kommunikáció és a tudásalapú társadalom felé mutató folyamatok felerősödése. A könyvtár- és információtudomány helyzetét a folyamatosan változó társadalmi igények vizsgálata és az eredményeinket elsődlegesen hasznosító könyvtári és információs szolgáltatások módszeres fejlesztése, ugyanakkor a tradíciót ôrző, naprakész közgyújteményi multifunkciós közvetítő szerep vizsgálata határozza meg."’

A fenti megállapításokból következő feladatok és főleg e feladatok végrehajtásának az eredményei önmagukért beszélnek, és egyre szélesebb körben nyernek elismerést. A pozitív szakmai fogadtatáshoz hozzájárulnak az ELTE BTK Könyvtár- és Információtudományi Intézete keretében múködő kilenc kutatási múhely eredményei, beleértve az itt folyó tehetséggondozási tevékenységet is. ${ }^{3}$ Mint az alábbi fejezetekben látni fogjuk, az egyes múhelyek a kutatások élvonalában járva úttörő szerepet játszanak számos új trend és paradigma kutatásában.

A kutatási múhelyek mellett a konferenciák is kiválóan reprezentálják a tudományos eredményeket. Az ELTE Bölcsészettudományi Karán 2015-ben megrendezett Valóságos könyvtár - könyvtári valóság II. konferencia előadásai és a jelen kötetben publikált tanulmányai csakúgy, mint a fentebb hivatkozott kilenc kutatási múhely eredményei, ${ }^{4}$ nélkülözhetetlen kiindulópontot képeznek mindazok számára, akik a könyvtár- és információtudomány legújabb, legizgalmasabb kutatásai iránt érdeklődnek.

Ennek a fejezetnek a terjedelme nem ad lehetőséget valamennyi aktuális trend, paradigma és kontextuális fejlemény áttekintésére, ezért két reprezentatív példán keresztül érzékeltetjük: a könyvtár- és információtudomány, illetve a könyvtárügy alapvető változások sorozatán megy keresztül. Szemlézve és helyenként idézve a közleményeket, amelyek az ELTE BTK Könyvtár- és Információtudományi Intézete két kutatási mûhelyében jöttek létre, merem remélni, hogy sikerül összefoglalni az Intézetben létrejött legújabb könyvtár- és információtudományi eredményeket.

Až e-könyvészet

Az e-könyvészet korunk könyvtár- és információtudományának, valamint könyvtárügyének egyik legizgalmasabb területe. Paradigmaváltásról van szó - de nem abban az értelemben, hogy az e-könyv a nyomtatott könyv hanyatlását jelentené. Az e-könyvészet néhány éve indult igazán fejlődésnek, ezért a vonatkozó kutatások java része a jövőben fog folyni.

Hazánkban az e-könyvészet kutatásában kulcsszerepet játszik Kerekes Pál, aki az ELTE BTK Könyvtár- és Információtudományi Intézetének címzetes egyetemi docen- 


\section{ÚJ EREDMÉNYEK A 2010-ES ÉVEK KÖNYVTÁR- ÉS INFORMÁCIÓTUDOMÁNYÁBAN}

seként az e-könyv kutatási múhelyt vezeti. Kerekes Pál az e-könyvészet - és tágabban a digitális kultúra - elismert szakértője. Az elektronikus könyvről enciklopédikus igénnyel megírt műve ${ }^{5}$ kapcsán kijelenthetjük, hogy úttörő szerepet játszott a hazai könyvtáros szakma tájékoztatásában. Társszerzője volt egy másik nagy hatású könyvnek ${ }^{6}$, amely az e-könyvészet tárgyában és az ELTE BTK Könyvtár- és Információtudományi intézete kiadásában jelent meg. Kerekes Pál alapítója, felelős szerkesztője a Könyvkonnektor elnevezésú blognak - pontosabban online bibliokult magazinnak -, amely a sokoldalú, naprakész és rendkívül színes tájékoztatást kombinálja a tudományos igényességgel, és ily módon évek óta felkelti a hazai kulturális élet érdeklődését.

Kerekes Pál jelenlegi kutatásai középpontjában elsősorban az e-könyv terület szolgáltatási problematikája áll: a könyvtári e-book kölcsönzés és/vagy könyvtári terjesztés, valamint a hazai szövegalapú elektronikus tartalom könyvtári szolgáltatásának helyzete. Kerekes azokból a korunkat alapvetően meghatározó viszonyokból indul ki, amelyek alapján az infokommunikációs technológiai forradalom hatására jelentős mértékú paradigmaváltás megy végbe a művelődési feltételrendszerben. Ez szükségszerűen mélyreható változásokat okozott olyan területeken, mint a könyvkiadás, a könyvterjesztés és - nem utolsó sorban - a könyvtári szolgáltatások. Kerekes rámutat, hogy az egyik ilyen nagy változás abban áll, hogy a referensz munka eszközei: a kézikönyvek, az alapmúvek és mindazon dokumentumok, amelyek a könyvtárak polcain kell, hogy sorakozzanak, gyakorlatilag ingyenes elektronikus tartalommá váltak a világhálón. Legalább ilyen jelentős változás, hogy az ingyenességen túl e tartalmak elérhetősége immár örökre felszabadult az idő és tér korlátai alól.

Ezeket a fejleményeket Kerekes Pál azért teszi vizsgálat tárgyává, mert mindezektôl a változásoktól sokan féltették nemcsak a könyvtárat, hanem magát a könyvet is -, de Kerekes messze nem osztja ezeket a félelmeket. A fejlődés őt igazolja: nap mint nap rácáfol ezekre a félelmekre, előítéletekre. Osztom Kerekes Pál nézetét, mely szerint a világháló nem lépett a könyvtárak helyébe, hanem éppen ellenkezőleg, ezek szolgáltatásait népszerűsítette.

Az így kialakult helyzetben tehát egyre fontosabb szerepet játszik mind a tudományos kutatásban, mind a kulturális életben az e-könyvek szolgáltatása, és ennek a feladatnak az ellátásában kiemelkedő szerep kell, hogy jusson a könyvtáraknak is. Amint Kerekes Pál megállapította: „A feladat nem teljesen ismeretlen, hiszen digitális tartalmakat eddig is szolgáltattak a könyvtárak. A teljesség igénye nélkül csak néhányat említve: Magyar Elektronikus Könyvtár, helytörténeti gyűjtemények digitalizált verziói, szak- és felsőoktatási könyvtárak szofisztikált e-kínálata. A beiratkozott tagok részéről azonban érthető igény, hogy a digitálisan készült és készletezett műveket, tehát a mai, tág értelemben vett kortárs szerzők alkotásait is elérhessék az interneten keresztül, könyvtári szolgáltatás keretein belül."’

A fentebb idézett fontos megállapítást Kerekes 2011-ben publikálta, de sem az igazsága, sem az aktualitása nem csökkent az elmúlt évek folyamán. Ugyanakkor az idő hozzásegített bennünket ahhoz, hogy számos további fontos aspektus vonatkozásában 


\section{SEBESTYÉN GYÖRGY}

tisztábban lássunk. 2016-ban Kerekes Pál és társszerzője, Kiszl Péter ezzel kapcsolatban a következő megállapítást teszik: „Az internetet övező egyik legenda az volt, és ez részben még ma is él, hogy az emberiség írott műveltsége a hálózaton egykor teljes egészében elérhetôvé válik, korlátozás nélkül, ingyenesen. Ez a gondolat mélyen beivódott a társadalmi köztudatba is, egyes múvelődési szektorok alapkövetelményként kezelték és kezelik ma is az értékekhez való hozzáférés térítésmentességét." ${ }^{\text {" }}$

Az internet vitathatatlanul kulcsszerepet tölt be az elektronikus könyvek szolgáltatásában, az elektronikus könyveknek hozzáférhetővé tételében. A világháló és az e-könyvészet tehát a legszervesebb egységben működve szétválaszthatatlan párost alkotnak. Az elvárás óriási, mert a legszélesebb körben fogalmazódik meg az az igény, hogy az e-könyvek ingyenes szolgáltatásként legyenek hozzáférhetők.

Mindennek konkrétan hogyan kell működnie? Mely szereplőknek kell átvállalniuk a költségeket? Kerekes Pálnak és Kiszl Péternek igen határozott álláspontja és konkrét elképzelése van: „Könyvek százezrei érhetők el, bennük magyar nyelven is gazdag gyűjteményekkel. Az eszköz lehet bármilyen digitális gépezet: asztali PC, note-book, táblagép, telefon és természetesen e-könyv-olvasó is. Vagy extra lehetőségeket is figyelembe véve: okos (smart) televízió, okos karóra (Apple), intelligens szemüveg. Elmondható és ma már történelmi távlatból is szemlélhető, hogy a kulturális médiatárak technikaitartalmi képességei feltételeinek biztosítására - a fogyasztói ingyenesség érdekében - a finanszírozás oldalán döntően az állam és szervezetei jelentek meg. Kormányzati vagy önkormányzati szintú intézmények kapcsolódtak be a digitális tudásmenedzsment megalapozásába, felépítésébe."9

Kerekes Pál és Kiszl Péter azon kevesek közé tartozik, akik az e-könyv kérdéskörében felismerik a legfontosabb komponenseket és problémaköröket, majd ezek alapján felteszik a kulcskérdéseket.

A legátfogóbb kulturális távlatokban, a legegyetemesebb kontextusokban gondolkodva világosan kell látni, hogy az elektronikus könyv szinne lépésével az emberiség olvasáskultúrájának egyik legnagyobb - ha nem a legnagyobb-paradigmaváltásának lehetünk egyszerre szereplöi és tanúi. A változás jelenleg az olvasási technikák és készségek vonatkozásában látható a legvilágosabban, amit így lehet összefoglalni: az olvasási metodika meróben új paradigmája.

A szerzőpáros e problémakört felismerve teszi fel a következő kulcskérdést: „Amint általánossá vált a képernyőről való olvasás, azonnal és magától értetődően felmerült a kérdés: megváltoztatja-e az olvasás metodikáját, és ha igen, miben, a hagyományos papírt felváltó elektronikus felületek megjelenése, illetve túlsúlyba kerülése?’10 Nézetem szerint ez a kérdés a kulcskérdések kulcskérdése, amelyre még nincs kimerítő válasz, legfeljebb részválaszok.

Tanulmányuk végén a szerzők felhívják a figyelmet Farkas Istvánnak, az egyik legismertebb e-könyv technológiai szakblog, az ekonyvolvaso.blog.hu szerkesztőjének megállapításaira: „Az nem kérdés, hogy az elektronikus olvasás lényegesen különbözik a papíralapútól. De hogy pontosan milyen téren és mennyiben, az megérne egy valódi tudományos kutatást, nagy mintával, sokféle szöveggel, jól ellenőrzött csoportképzéssel, ellenőrzött 


\section{ÚJ EREDMÉNYEK A 2010-ES ÉVEK KÖNYVTÁR- ÉS INFORMÁCIÓTUDOMÁNYÁBAN}

olvasási környezettel. Mint elkötelezett elektronikusolvasás-párti, az a tapasztalatom és meggyőződésem, hogy vannak „olvasástípusok”, olvasási profilok, amelyekben általában kellemesebb az elektronikus tartalomfogyasztás (nem feltétlenül mindenkinek). Más profilokban (feladatoknál) meg én is inkább a nyomtatott olvasást választom. De egyértelmú, általánosító kijelentést nem tennék, hogy egyik vagy másik olvasási mód jobb.”11

Mint a fenti érvelésből láthatjuk, az elektronikus könyv által generált olvasási paradigmaváltás tudományos feldolgozása még a kezdeteknél tart. Sokkal jobb a helyzet az e-könyv fogalmának definíciójával kapcsolatban. Az elektronikus könyv fogalmának tisztázásában, pontosításában fontos előrelépésnek tekintendő Kerekes Pál és Kiszl Péter közleménye, amely az Iskolakultúra című szakfolyóiratban jelent meg. ${ }^{12}$

A köztudatban ugyanis az e-könyvrôl eléggé pontatlan kép él, és ezt nemcsak fenntartják, de esetenként fokozzák a médiapiacon folyó kíméletlen versenyből fakadó különböző, elsősorban kommunikációs üzleti fogások. Ezért tartom fontosnak, hogy kiemeljem a szerzôk rendkívül találó, világos, mindenki számára könnyen érthető megfogalmazását az e-könyv fogalmáról és funkcióköréről: „Az elektronikus könyv - nem értve bele a fogalomba a webes szöveg-tartományokat, mint például blog, fórum, intézményi honlap, személyi site - kulturális médiummá, a múvelődés, a tudáselsajátítás, a szövegre épített szakmai és hobbi időtöltés keret-technikájává fejlődött. A digitális irodalom a kezdeti extrémizmusból igényes élménygyűjtő és élményszállító instrumentummá finomodott.”13 A definíció világos, de számos kérdés még tisztázandó: „A Gutenberg-galaxis és az olvasás világa megváltozik. A jövő olvasó emberének kulturális, tanulási igényeire az informatika döntő hatással lesz. Milyen technika irányítása alá kerül a digitális műveltség? Milyen eszköz lesz a következő évtizedek e-bookja? Egyáltalán könyvnek vagy 'app'-nak (applikációnak) fogjuk nevezni a tartalmi és formai átlényegülést megélő digitálisszöveg-produktumot? Biztosan talán csak annyit állapíthatunk meg: az e-könyv egy új médium, amely nyomtatott elődjéhez képest könnyebben elérhetővé teszi - a digitális tartalom útján - a szépirodalmi, tudományos, szórakoztató alkotásokat."14

\section{Virtualizálódó kulturális örökeségünk a körülöttünk virtualizálódó világban}

E fejezet címét Fodor János kifejezésmódjának segítségével fogalmaztam meg. Fodor János (az ELTE BTK Könyvtár- és Információtudományi Intézetének adjunktusa, a Web 2.0 Library 2.0, valamint a Tartalomszolgáltatás és hálózati tájékoztatás kutatási múhelyek vezetője) több mint másfél évtizede foglalkozik internetes közmúvelődési tájékoztatással, széles körben ismertek a kulturális örökség és a digitális kultúra közötti kapcsolatok, az e-könyvészet, valamint a közösségi médiumok könyvtári alkalmazásainak területein elért kiváló eredményei. E fejezet keretében a Fodor János által is kutatott, interdiszciplinárisan összefüggő három terület legjelentősebb fejleményeit kívánom bemutatni.

\section{Kulturális örökeségünk és az infokommunikációs technológiák fejlödése}

Fodor János kutatásai számos pragmatikus jelentőségú következtetéssel gazdagítják korunk könyvtár- és információtudományát, amelyek igen hasznos szerepet játszanak ab- 


\section{SEBESTYÉN GYÖRGY}

ban, hogy korunk könyvtárügye ne essen áldozatul bizonyos illúzióknak, amelyek széles körben kötődnek akár a digitalizáláshoz, akár pedig a világhálóhoz - különös tekintettel a szemantikus webre.

A kulturális örökség archiválása elsőrangú feladat, és egyben hatalmas kihívás volt és marad. Korunk IT technológiai vívmányai elvben minden idők leghatékonyabb megoldásait ígérik. A digitális könyvtárak, különösen kombinálva egyéb digitális médiumokkal, olyan virtuális tudásvagyon felépítésének az alapját képezik, amelyek alig néhány évtizeddel ezelőtt kizárólag a science fiction múfajába illettek volna. Ennek ellenére a könyvtáros szakma nem tud maradéktalanul örülni sem ennek a helyzetnek, sem a belőle következô perspektíváknak. Elméletben minden abszolúte pozitívnek tűnik, ám a gyakorlatban történő fejlesztések számos buktató kockázatát hordozzák. A kép tehát távolról sem tekinthető egyértelműen pozitívnak, és Fodor János kutatásai konkrét kockázatokat tárnak fel.

Melyek a legveszélyesebb buktatók? Az egyik kétségtelenül az a tradicionális jelleggel létező távolság, amely fennállhat a könyvtáros és az informatikus szakma között. Nem zárható ki annak a veszélye, hogy ez a távolság növekedni fog, és egyre nehezebb lesz áthidalni. A másik buktató paradox módon éppen az infokommunikációs technológiák fejlettségéből és minden területet meghódító eredményességéből következik. A digitalizált könyvtári tartalmak csak egy relatíve szúk, és nem túl feltűnő részét képezik annak a rendkívül széles választéknak, az irdatlan tömegű információ- és adathalmaznak, amely a hálózaton manapság elérhető.

Mi a megoldás a fenti helyzetre? A helyzet komplexitásából következően számos hatékony megoldás koordinált alkalmazására van szükség. Egyetértek Fodor Jánossal abban, hogy az infokommunikációs technológiát alkalmazó könyvtári szolgáltatások hatékonyságának egyik fontos feltétele, hogy a hagyományos könyvtári kontextusban múködő tudós könyvtáros - ha tetszik, bibliothecarius doctus - szerepköre felértékelődjön.

A digitális tartalomfejlesztés fokozódó szerepe szükségszerūen maga után vonja az e-olvasás térhódítását, növekvő arányát, úgy is fogalmazhatunk, hogy ezek szétválaszthatatlan egységet alkotnak, hiszen egyazon jelenség két ellentétes pólusát képezik. Fodor János kutatásaiban is világosan kirajzolódik ez a szétválaszthatatlan egység.

Fodor Jánost a digitális tartalomfejlesztés során szerzett tapasztalatai teszik képessé arra, hogy reálisan értékelje az e-könyvészet erősödő jelentőségét, az e-olvasás pozitív szerepét. E szemléletre nagy szükség van, mert mint minden korszakalkotó technológiával szemben, az e-book kapcsán is számos előítélet keletkezett.

Ezek az előítéletek nem ritkán tudományos rendezvényeken is hangot kapnak. Az e-olvasás tárgyában az ELTE Bölcsészettudományi Karán rendezett vitán a legmarkánsabb kritikák megfogalmazója Békés Márton volt, aki számos érvet sorakoztatott fel nézeteinek igazolására. Fodor János meggyőzően tudott ezekkel a nézetekkel vitába szállni. Idézzük a legfontosabb érvelését: „Békés Márton Szilícium-völgyi nagyvállalatokkal szembeni ellenérzéseire reagálva szögezzük le: a nyomtatott könyvkiadás sem mentesebb a multinacionális üzleti érdekektől. Míg a könyvkiadók és a szellemi műhelyek har- 


\section{ÚJ EREDMÉNYEK A 2010-ES ÉVEK KÖNYVTÁR- ÉS INFORMÁCIÓTUDOMÁNYÁBAN}

cot vívnak egymással és a nemzetközi konkurenciával, vagy elkeseredetten küzdenek a fogyatkozó pályázati támogatásokért, az olcsó és korlátlanul hozzáférhető elektronikus szövegek közelebb vihetik a szerzőket a valós olvasói piachoz, organikusan kialakuló közönségükhöz. Az e-könyvkultúra és a webes tájékozódás szimbiózisa megkönnyítheti az alkotó írók, szerzők megismerését, estjeik, kultuszuk kiadói menedzselését." ${ }^{15}$

\section{A közösségi média és a könyvtárak kölcsönhatásai}

Nagy téma ez a könyvtár- és információtudományi kutatásokban, világszerte számos közlemény jelenik meg ezen a területen. Az álláspontok és a tapasztalatok nagyon sokfélék, sőt ellentmondóak. Terra Dankowski az American Libraries szakfolyóiratban csupa pozitív fejleményrôl számol be. Közleményéből kitűnik, hogy a New York Public Library a Twitteren olyan idézeteket tett közzé, amelyekben hírességek dicsérik, esetenként magasztalják a könyvtárakat, és ennek hatására 2012 szeptemberében az átlagoshoz képest 30 százalékkal nőtt a beiratkozások száma! Más amerikai könyvtárak a Facebook és a YouTube segítségével népszerúsítették a könyvtárosok hivatását, és ezáltal képesek voltak a társadalom széles körű szimpátiájának felkeltésére. ${ }^{16}$

Ben Malczenski a Public Libraries Online elektronikus szakfolyóiratban a fentivel szöges ellentétben lévő, teljes mértékben negatív és pesszimista álláspontot képvisel, mert egész közleményében azt taglalja, hogy miért nem múködik a közösségi média, ha könyvtári célokra próbálják felhasználni. ${ }^{17}$

Visszatérve Fodor János kutatásaira: a közösségi média és a könyvtárak kölcsönhatásai tekintetében az ő következtetései igen tárgyilagosak, mentesek a túlzottan optimista vagy túlzottan pesszimista állásfoglalásoktól. Sokan és sokszor elfelejtkeznek arról, hogy a közösségi médiákat nem kifejezetten a könyvtárak számára fejlesztették ki, és annak ellenére, hogy számos könyvtártípus közösségi funkciókat is betölt, a találkozási pontok rendszerint nem magától értetődőek. Fodor János ezt az álláspontot képviseli, és ezt számos érvvel és ténnyel támasztja alá.

A fentiek kapcsán Fodor János a közösségi háló és a könyvtári jövőkép vonatkozásában a következőket állapítja meg: „Épphogy megszoktuk a könyvtár »hagyományos« hálózati jelenlétének lehetőségeit, a technológiai újdonságok beépítésével weboldalaink fejlődése a Lankes-féle szempontokkal is harmonikusan összeegyeztethetőnek tűnt: honlapunk mint biztos hírforrás, kontrollált, minőségi tartalommal, egyedi, barátságos vagy professzionális arculattal, online adatbázisokkal és segítő, interaktív szolgáltatások komplexitásával fogadta a virtuális látogatókat éjjel-nappal."18

Ám úgy tűnik, hogy jelenleg mindez már a múlté, mert a fenti szisztéma a mai viszonyok között már nem múködik a korábbi eredményességgel, legalábbis a közösségi médiában való hatékony szereplés szempontjából. Vagy mégis? Fodor János ennek a „mégisnek”, vagyis a „hagyományos” hálózati jelenlét átmentésének, a közösségi médiában történő újrahasznosításának vonatkozásában vet fel rendkívül fontos kérdéseket: „Mi reprodukálható mindebből a közösségi médiában, ahol mindenki mást és máskor lát, ahol tartalmaink versenykényszerbe kerülnek egészen más jellegű és minőségű infor- 


\section{SEBESTYÉN GYÖRGY}

mációkkal? Hogyan érzékeltethető az oktató-segítő környezet, szolgáltatásaink komplexitása és tudástáraink bősége, ha követőink, kedvelőink alig lépnek oldalunkra, s jelenlétünket valójában csak esetleges ütemezésben eléjük kerülő üzeneteink képviselik?’19

Nagyon fontos, rendkívüli éleslátással felvetett kérdések ezek, amelyek a fejlődés jelenlegi szakaszában csak nagyon hiányosan válaszolhatók meg. Jelentős lépést tettünk meg azonban a sikeres megoldások irányába, amikor Fodor János definiálta azokat a kulcsproblémákat, amelyek akadályozzák a közösségi médiában betöltendő sikeres könyvtári szerepvállalást.

\section{Irodalom}

${ }^{1}$ A könyvtári terület stratégiai céljai 2003-2007 között. Jövőkép. Forrás: http://ki.oszk.hu/[-] content/konyvtari-terulet-strategiai-celjai-2003-2007-kozott [2016. január 8.]

${ }^{2}$ KISZL Péter: Tudományos örökség és gyorsuló fejlődés - könyvtárosképzés az Eötvös Loránd Tudományegyetemen. = Könyvtári Figyelő, 25. (61.) 4. sz. 2015. 448. p.

${ }^{3}$ A kutatási műhelyek felsorolását, múködésének és eredményeinek részletes leírását lásd: BARÁTNÉ HAJDU Ágnes - BODA Gáborné KÖNTÖS Nelli: Tehetséggondozás az egyetemi könyvtárosképzésben. = Könyvtári Figyelő, 25. (61.) 2015. 3. sz. 302-306. p.

${ }^{4}$ BARÁTNÉ HAJDU Ágnes - BODA Gáborné KÖNTÖS Nelli 2015: i. m. 302-306. p.

${ }^{5}$ KEREKES Pál: E-book kalauz: az elektronikus könyv kisenciklopédiája. Budapest, Kossuth kiadó, 2011. 200 p.

${ }^{6}$ KEREKES Pál - KISZL Péter - TAKÁCS Dániel: E-könyvészet: a digitális könyvkultúra alapvonásai. Budapest, ELTE-BTK Könyvtár- és Információtudományi Intézete, 2013. 310 p.

${ }^{7}$ KEREKES Pál: Az elektronikus könyvek kölcsönzésének problémái: szövegbérlet-, textlízingkonstrukciók megjelenése. = Tudományos és Műszaki Tájékoztatás, 58. évf. 5. sz. 2011. 191. p.

${ }^{8}$ KEREKES Pál - KISZL Péter: Univerzális szövegelérés és olvasói integráció: az elektronikus könyv kulturális és oktatási vetületei. = Híd, 80. évf. 7. sz. 2016. 70. p.

${ }^{9}$ KEREKES Pál - KISZL Péter 2016: i. m. 71. p.

${ }^{10}$ KEREKES Pál - KISZL Péter: „Múszálas” olvasás - mérlegen a nyomtatott és az elektronikus szöveg. = Könyv és Nevelés, 16. évf. 4. sz. 2014. 8-15. p.

${ }^{11}$ FARKAS István: Diszklémer. Forrás: http:// ekonyvolvaso.blog.hu/2014/08/30/villamposzt[-] _becsengetes [2016. január 8.]

${ }^{12}$ KEREKES Pál - KISZL Péter: Az elektronikus könyvről - oktatáson innen és túl. = Iskolakultúra, 25. évf. 3. sz. 2015. Forrás: http://epa.oszk.hu/00000/00011/00193/pdf/[-] EPA00011_iskolakultura_2015_03_056-071.pdf [2016. január 8.]

${ }^{13}$ KEREKES Pál - KISZL Péter 2015: i. m. 56. p.

${ }^{14}$ KEREKES Pál - KISZL Péter 2015: i. m. 57. p.

${ }^{15}$ FODOR János: E-olvasásról a tagadás tükrében: egy bölcsészkari vita tanulságai. = Könyvtári Figyelő, 24. (60.) évf. 4. sz. 2014. 484. p.

${ }^{16}$ DANKOWSKI, Terra: How Libraries Are Using Social Media. = American Libraries Magazine, July 16, 2013. Forrás: https://americanlibrariesmagazine.org/2013/07/16/how-[-] libraries-are-using-social-media [2016. január 8.] 
ÚJ EREDMÉNYEK A 2010-ES ÉVEK KÖNYVTÁR- ÉS INFORMÁCIÓTUDOMÁNYÁBAN

${ }^{17}$ MALCZEWSKI, Ben: Why Social Media Isn't Working For Your Library. = Public Libraries Online, May 1, 2013. Forrás: http://publiclibrariesonline.org/2013/05/why-social-[-] media-isnt-working-for-your-library [2016. január 8.]

${ }^{18}$ FODOR János: Könyvtári szereplehetőségek a közösségi médiában. = Könyvtári Figyelő, 25. (61.) évf. 4. sz. 2015. 490. p.

${ }^{19}$ FODOR János 2015: i. m.

Sebestyén György az ELTE BTK Könyvtár- és Információtudományi Intézetének professor emeritusa. 1998-2012 között a Könyvtártudományi Tanszék, 2000-2013 között a Könyvtártudományi Doktori Program vezetője, 2007-2011 között az Informatikai és Könyvtártudományi Intézet igazgatója. 